\title{
MOLUSKA TEMUAN DI DESA SAKO SEBAGAI SUMBER PEMBELAJARAN SEJARAH
}

\author{
Oleh: Sutomo ${ }^{\star}$, Ahmad Zamhari ${ }^{\star \star}$ \\ *Mahasiswa Program Studi Pendidikan Sejarah FKIP Universitas PGRI Palembang \\ ${ }^{* *}$ Dosen Program Studi Pendidikan Sejarah FKIP Universitas PGRI Palembang
}

\begin{abstract}
ABSTRAK
Percandian Bumiayu di Desa Tanah Abang kabupaten Penukal Abab Lematang llir berasal dari masa Sriwijaya. Candi Bumiayu identik dengan arca dan relief yang kaya dengan nilai sejarah dan budaya. Arca di candi Bumiayu dapat dimanfaatkan sebagai sumber pembelajaran sejarah. Rumusan masalah penelitian ini: Apakah pengarcaan di percandian Bumiayu dapat dijadikan sebagai sumber pembelajaran IPS terpadu (sejarah) kelas VII SMP Sriguna Palembang?. Tujuan penelitian ini: (1) Untuk mengetahui lokasi serta lingkungan alam yang terdapat di Candi Bumiayu agar dapat dijadikan sebagai sumber pembelajaran IPS terpadu (sejarah). (2) Untuk mengetahui analisis Pengarcaan dari Candi 1 Bumiayu agar dapat dijadikan sebagai sumber pembelajaran IPS terpadu (sejarah).(3) Untuk mengetahui analisis Pengarcaan dari Candi 3 Bumiayu sebagai sumber pembelajaran IPS terpadu (sejarah). Metode yang digunakan dalam penelitian deskriptif kualitatif. Teknik pengumpulan data yaitu: dokumentasi, observasi, wawancara. Teknik analisis data yang digunakan adalah teknik analisis model analisis interaktif. Kesimpulan penelitian: Pengarcaan di candi Bumiayu yang terdapat di candi 1 dan candi 3 Bumiayu bercorak Hindu. Pengarcaan di candi Bumiayu dapat menambah pengetahuan siswa tentang sejarah lokal di Sumatera Selatan.
\end{abstract}

Kata Kunci: Moluska, Sumber Pembelajaran, Sejarah.

\section{A. PENDAHULUAN}

Desa Sako terletak di kecamatan Rambutan kabupatennya Banyuasin Sumatera Selatan. Desa ini diberi nama Sako karena pada saat itu kesultanan Palembang Darussalam sedang membangun masjid. Maka kesultanan Palembang meminta bantuan kepada warga Parung Priyayi untuk menyumbang sako (tiang) masjid, maka terdengarlah anak keturunan Ariodillah dan mereka sanggup untuk mengambilkan sako tersebut, setelah akan diantarkan terdengarlah berita bahwa sako yang diminta oleh kesultanan Palembang Darussalam sudah cukup. Dan akhirnya sako (tiang) yang sudah siap diantarkan tersebut tidak jadi diantarkan dan tetap ditempatnya hingga membusuk ditempat pemangkalan kayu. Tempat itu akhirnya disebut Sako (Kanang, 2010:4).

Para leluhur desa Sako dahulunya membuat desa ini sebelum didiami dirajah sesajen sepanjang 500 Meter, yaitu untuk menangkal dari serangan binatang buas dan penjahat yang berniat jahat, setelah itu barulah membuat rumah dan tempat peribadatan. Pada saat itu nenek moyang Sako beradu ilmu dengan nenek moyang Sungai Dua dan sebelum bertanding nenek moyang berpesan kepada pengikutnya kalau suatu saat saya kalah dan meninggal dunia tolong kalian jangan bersedih namun kalian siapkan pesta kemenangan dengan gendang tetawak diringi dengan pencak silat dan hiasi aku. Dan sampailah pada hari beradu ilmu kanuragan dan nenek moyang meninggal sesuai dengan pesan yang telah disampaikan maka dibuatkanlah pesta dengan tabuan gendang tetawak diiringi dengan pencak silat (Kanang, 2010:1).

Dari hasil temuan awal di lapangan di desa Sako yang dilakukan pada tanggal 23-24 Desember 2016 dengan kedalaman galian $0 \mathrm{~cm}$ di atas tanah bekas galian 
proyek tanah yang sudah digali sedalam 4,5 meter ditemukan fosil-fosil moluska yang terjebak di tanah lempung yang menjadi batu, temuan semakin luas hampir di seluruh lahan tanah galian di desa Sako di kedalaman 4,8 meter dari permukaan tanah sebelum digali oleh proyek galian tanah. Tidak aneh apabila di desa tetangga desa Sako ada satu desa yang diberi nama desa Tanjung Kerang.

Temuan fosil moluska di desa Sako menunjukkan bahwa fosil moluska yang ditemukan merupakan fosil moluska laut. Beranjak dari temuan awal ini peneliti tertarik untuk meneliti apakah fosil moluska yang ditemukan di desa Sako dapat dimanfaatkan sebagai sumber pembelajaran sejarah.

\section{B. METODE PENELITIAN}

Metode penelitian yang digunakan dalam penelitian ini adalah metode kualitatif deskriptif, untuk mendeskripsikan data dan informasi moluska temuan desa Sako yang dimanfaatkan sebagai sumber pembelajaran sejarah.

\section{Teknik Pengumpulan Data}

Dalam melakukan penelitian ini, peneliti menggunakan teknik observasi, wawancara dan dokumentasi.

\section{Validitas Data}

Validitas data menurut Sutopo (2006:229), guna menjamin dan mengembangkan validitas data yang akan digunakan dalam penelitian ini, teknik pengembangan validitas data yang biasa digunakan dalam penelitian kualitatif yaitu teknik trianggulasi. Trianggulasi merupakan cara yang paling umum digunakan bagi peningkatan validitas data dalam penelitian kualitatif. Dalam kaitannya dengan hal ini Patton (1984) menyatakan bahwa ada empat macam teknik trianggulasi, yaitu (1) trianggulasi data yaitu peneliti dalam mengumpulkan data wajib menggunakan beragam sumber berbeda-beda yang disajikan. (2) triangulasi metode, yaitu hasil peneliti mengumpulkan data sejenis tapi menggunakan metode yang berbeda. (3) trianggulasi peneliti, yaitu hasil penelitian dapat diuji validitasnya oleh beberapa peneliti lain. (4) trianggulasi teori, yaitu peneliti menggunakan perspektif lebih dari satu teori dalam membahas permasalahan yang dikaji (Pranoto, 2006:85).

\section{Teknik Analisis Data}

Teknik analisis data menurut Sugiyono (2009:23), proses analisis dilakukan sejak awal bersamaan dengan proses pengumpulan data dalam bentuk refleksi. Peneliti menggunakan model analisis interaktif. Dalam model ini terdapat beberapa komponen analisisnya yaitu:

Pengumpulan Data: Pengumpulan data merupakan proses yang berlangsung sepanjang penelitian, dengan menggunakan seperangkat instrumen yang telah disiapkan, guna memperoleh informasi data melalui observasi, wawancara dan mencatat dokumen.

Reduksi Data: Reduksi data menunjukkan proses menyeleksi, memfokuskan, menyederhanakan, mengabstraksikan dan mentransformasikan data mentah yang muncul dalam penulisan dari catatan lapangan.

Display Data: Display Data adalah usaha merangkai informasi yang terorganisir dalam upaya menggambarkan kesimpulan dan pengambilan tindakan (Usma, 2014:71).

Verifikasi dan Penarikan Kesimpulan: Verifikasi dan penarikan kesimpulan merupakan aktifitas analisis, dimana pada pengumpulan data, seorang analisis bisa memutuskan apakah sesuatu bermakna atau tidak mempunyai keteraturan, pola, penjelasan, kemungkinan komposisi( Arikunto, 2013:53). Model analisis interaktif dapat digambar dengan skema sebagai berikut:

\section{HASIL DAN PEMBAHASAN Kondisi Geografis Desa Sako}

Wilayah desa Sako dilihat dari topografi ketinggian berada pada 4-20 m 
ketinggian dari permukaan laut dengan keadaan curah hujan rata-rata 1982,5 $\mathrm{mm} /$ tahun, serta suhu rata-rata harian adalah $30^{\circ} \mathrm{C}$ dengan kelembaban udara rata-rata $70 \%$ pertahun. Secara geografis desa Sako kecamatan Rambutan kabupaten Banyuasin berbatasan dengan:

a) Sebelah Utara berbatasan dengan desa Manten

b) Sebelah Selatan berbatasan dengan desa Gelebak Dalam.

c) Sebelah Timur berbatasan dengan desa Tanjung Marbu.

d) Sebelah Barat berbatasan dengan desa Pangkalan Gelebak.

Luas Desa Sako: 2.801 ha, Lahan sawah/lebak: 700 ha, lahan kering (tegalan): 1851 ha, rawa-rawa: 250 ha. Jarak desa ke ibu kota Propinsi: $19 \mathrm{Km}$, jarak desa ke ibu kota Kabupaten: $83 \mathrm{Km}$, jarak desa ke ibu kota Kecamatan: $8 \mathrm{Km}$.

Sosial Ekonomi Masyarakat Desa Sako, mata pencarian: Petani/pekebun: 1035 orang, buruh tani: 25 orang, PNS: 16 orang, Swasta: 74 orang, karyawan swasta: 7 orang.

\section{Temuan Fosil Moluska Desa Sako}

Dari hasil temuan lapangan di desa Sako yang dilakukan pada tanggal 23-24 Januari 2016 dengan kedalaman galian pada tanggal 23 Januari 2016 yaitu $20 \mathrm{~cm}$ dan pada penggalian tanggal 24 Januari 2016 kedalaman ditambah $10 \mathrm{~cm}$ sehingga mencapai kedalaman $30 \mathrm{~cm}$, dalam penggalian ini dilakukan di atas tanah bekas galian proyek tanah yang sudah digali sedalam 4,5 meter, jadi temuan fosil moluska ini berada di kedalaman 4,8 meter dari permukaan tanah sebelum digali oleh proyek galian tanah. Dalam penggalian ini peneliti menemukan fosil moluska yang sekarang tersebar di antara samudra Pasifik, samudera Hindia.

Data temuan lapangan di desa Sako dapat dikelompokkan sebagai berikut:

Tellinidae rostrata. Hewan ini memiliki ciriciri: cangkang yang membengkak pada bagian yang hampir bersentuhan dengan sirip daging. Tellinidae rostrate ini hidup di air asin dan tersebar di laut sekitar Malaysia (Oliver, 2004:309).

Drillia suturalis. Merupakan moluska yang memiliki cangkang yang menjulang tinggi keatas seperti menara, dan memiliki punggung yang kecil. Moluska Drillia suturalis ini hidup di air asin dan tersebar di Timur Selatan Asia (Oliver, 2004:297).

Oliva elegans memiliki cangkang yang montok dengan puncak menara yang sangat pendek dan tajam. Oliva elegans ini merupakan moluska yang hidup di air asin dan tersebar di laut indo pacifik (Oliver, 2004:208).

Acmaeidae borneensis memiliki puncak yang tertekan sempurna yang berbentuk seperti bantal yang memiliki ruang yang sempit, serta mempunyai titik pusat ditengah. Acmaeidae borneensis ini hidup di air asin dan tersebar di pantai borneo Utara hingga di laut Indo Pasifik (Oliver, 2004:26).

Architec tonicidae perdix memiliki cangkang yang berbentuk spiral dan menonjolkan bentuk seperti jahitan yang mengalur luas dan cembung. Architec tonicidae perdix ini hidup di air asin dan tersebar di Australia Utara ke Malaya dan Srilanka (Oliver, 2004:49).

Fusinus colus memiliki cangkang yang agak bersudut dengan puncak menara yang tinggi. Puncak yang berada di punggung bukit berpilin seperti tali yang bagus dan melingkar berulir. Fusinus colus ini hidup di air asin dan tersebar di Indo Barat Pasifik (Oliver, 2004:200).

Siliquaria ponderosa memiliki cangkang yang berulir lekat bergulung kemudian tumbuh secara sembarangan. Siliquaria ponderosa ini hidup di air asin dan tersebar di laut Australia (Oliver, 2004:51).

Conidae generalis memiliki cangkang dibagian puncak yang agak kempes dan memiliki puncak menara cekung yang tajam, yang berwarna gelap atau coklat dan bintik-bintik putih. Conidae generalis ini 
hidup di air asin dan tersebar di Indo Pasifik (Oliver, 2004:272).

Discors lyratum memiliki cangkang yang bengkak dan padat yang memahat dan mempunyai garis, memiliki pantat yang lebih kuat dan punggung bukit jelas bersih dan bergaris membatasi dengan yang depan. Discors lyratum ini hidup di air asin dan tersebar di Indo Pasifik (Oliver, 2004:304).

Dentalium elephantinum merupakan jenis moluska yang membujur dan memiliki sembilan garis di punggung bukit, dan memiliki warna yang menjilid dengan keteduhan seperti warna hijau lebih gelap di akhir lebih luar dan warna putih di bibir. Dentalium elephantinum ini hidup di air asin dan tersebar di Indo Pasifik (Oliver, 2004:313).

Latirus polygonus memiliki cangkang yang berpilin dipunggung seperti jahitan, memiliki tujuh bukit bubungan yang berpilin melikar atau berulir menurun pada badan dan memiliki punggung bukit yang kuat. Latirus polygonus ini hidup di air asin dan tersebar di Indo Pasifik (Oliver, 2004:198).

Biplex perca memiliki cangkang bergelombang yang diratakan dan mengenai sirip perut yang diperluas yang diratakan $180^{\circ}$ di tiap-tiap punggung bukit dan memiliki tujuh ulir pada atas badan. Biplex perca ini hidup di air asin dan tersebar di Indo Barat Pusat Pasifik (Oliver, 2004:152).

Tridacna squamosa memiliki cangkang yang rendah dan kuat, serta bukit punggung memiliki lima bubungan radial masing-masing membawa cangkang yang berbentuk bengkok. Tridacna squamosa ini hidup di air asin dan tersebar di Indo Pasifik (Oliver, 2004:307).

Hindsia magnifica memiliki cangkang puncak menara tinggi yang terbatas di pompa spiral punggung bukit atau bubungan tulang rusuk diatas badan, dengan bibir yang melebar secara internal dan memiliki warna coklat putih yang menjilid. Hindsia magnifica ini hidup di air asin dan tersebar di Indo Pasifik (Oliver, 2004:192).

Paphia amabilis memiliki cangkang yang cekung agak diperpanjang di depan paruh menutup punggung bukit bubungan, sari sepusat dengan bagus dan berliku-liku, bentuk coklat. Paphia amabilis ini hidup di air asin dan tersebar di Indo Pasifik (Oliver, 2004:306).

Turbinidae petholatus memiliki cangkang yang berpola teladan bagian puncak menara kurang lebih tinggi dari badan. Turbinidae petholatus ini hidup di air asin dan tersebar di Indo Pasifik (Oliver, 2004:38)

Struthiolaria papulosa-papulosa memiliki cangkang yang bersudut mengembang dan padat pada bagian bahu, spiral mengikat lingkaran ulir pada badan yang agak kempes dan mempunyai bentuk yang kasar. Struthiolaria papulosa-papulosa ini hidup di air asin dan tersebar di Indo Pasifik (Oliver, 2004:89).

Pleurotomariidae memiliki cangkang yang berulir dan memiliki garis seperti benang yang berpilin melingkar dari atas menara cangkang. Pleurotomariidae ini hidup di air asin dan tersebar di Indo Pasifik (Oliver, 2004:17).

Cypraeidae onyx memiliki cangkang dasar dan sisi berwarna coklat sangat gelap kehitaman. Cypraeidae onyx ini hidup di air asin dan tersebar di selatan Afrika, pantai Afrika ke Kenya, Madagaskar, Mauritius, Indian samudra Utara, Indonesia, Pilipina, dan Jepang Selatan (Oliver, 2004:92).

Turritellidae memiliki lima puluh jenis didalam jenisnya, dan hidup di iklim tropis, serta mempunyai cangkang yang panjang. Pleurotomariidae ini hidup di air asin dan tersebar di Indo Pasifik (Oliver, 2004:46). 
T. terebra memiliki puncak menara yang sangat tipis dan memiliki dua puluh lima lingkaran ulir yang dibulatkan dicangkang, mempunyai enam punggung bukit pilinan dan empat pilinan diatas menara yang menerangi berwarna coklat. T. terebra ini hidup di air asin dan tersebar di Indo Pasifik (Oliver, 2004:47).

Latirus polygonus memiliki cangkang yang berpilin dipunggung seperti jahitan, memiliki tujuh bukit bubungan yang berpilin melikar atau berulir menurun pada badan dan memiliki punggung bukit yang kuat. Latirus polygonus ini hidup di air asin dan tersebar di Indo Pasifik (Oliver, 2004:198).

Karang terdapat di dasar laut yang yang bersimbiosis dengan tumbuhan alga yang disebut Zooxanthellae. Karang ini terdapat di air asin.

Paphia amabilis memiliki cangkang yang cekung agak diperpanjang di depan paruh menutup punggung bukit bubungan, sari sepusat dengan bagus dan berliku-liku, bentuk coklat. Paphia amabilis ini hidup di air asin dan tersebar di Indo Pasifik (Oliver, 2004:306).

Spisula elliptica memiliki cangkang yang pata dan bujur telur, berwarna putih kotor tetapi terkadang berwarna biru, hijau atau kuning cincin. Hidup di kerikil atau pasir berlumpur tersebar di Timur Utara Atlantik (Oliver, 2004:308).

Strombus latus memiliki menara yang pendek dan lancip serta bagian badan mengembang serta berwarna kuning. Pleurotomariidae ini hidup di air asin dan tersebar di Laut Australia, Samudra India dan Pilipina (Oliver, 2004:65).

Tellinidae rostrata memiliki cangkang yang membengkak pada bagian yang hampir bersentuhan dengan sirip daging.
Tellinidae rostrate ini hidup di air asin dan tersebar di Luar Malaysia (Oliver, 2004:309).

Cerestoderma edule memiliki dua puluh lima tulang rusuk, berwarna coklat kuning terkadang putih. Cerestoderma edule ini hidup di air asin dan tersebar di Indo Pasifik (Oliver, 2004:304).

Anadara maculosa memiliki cangkang yang berbentuk perahu, dan memiliki lapisan cangkang yang tebal. Anadara maculosa ini hidup di air asin dan tersebar di Indo Pasifik (Oliver, 2004:301).

Aequipecten opercularis memiliki cangkang yang keras dan memiliki sekitar dua puluh tulang rusuk telinga yang sama. Aequipecten opercularis ini hidup di air asin dan tersebar di Indo Pasifik (Oliver, 2004:302).

Olividae reticulate memiliki cangkang yang puncak menaranya rendah yang dalamnya terdapat seperti jahitan sempit, berwarna putih. Olividae reticulate ini hidup di air asin dan tersebar di Indo Pasifik (Oliver, 2004:209).

Tridacna squamosa memiliki cangkang yang rendah dan kuat, serta bukit punggung memiliki lima bubungan radial masing-masing membawa cangkang yang berbentuk bengkok. Tridacna squamosal ini hidup di air asin dan tersebar di Indo Pasifik (Oliver, 2004:307).

Pteria leventi memiliki cangkang agak dipompa pada sisi yang mengenai sirip perut dan membingkai garis yang mudah pecah serta berwarna coklat. Pteria leventi ini hidup di air asin serta tersebar di Indo Pasifik (Oliver, 2004:300).

Pinna incurve memiliki cangkang yang tebal tetapi mudah pecah, memiliki lapisan cangkang yang transparan dan lapisan dalam berkilau dengan jernih. Pinna incurve ini hidup di air asin dan tersebar di 
Samudra Indian, laut Cina Selatan, dan laut Astralia Utara (Oliver, 2004:300).

\section{Pembahasan}

Dalam penelitian ini peneliti meneliti tentang fosil moluska yang terdapat di desa Sako kecamatan Rambutan kabupaten Banyuasin. Fosil adalah hewan dan tumbuhan yang mati jutaan tahun yang membusuk. Pembusukan terjadi pada bagian tubuhnya yang keras misalnya tulang, terawetkan di dalam batuan menjadi fosil. Fosil menunjukkan pada kita tanaman dan hewan jenis apa saja yang hidup jutaan tahun lalu. Beberapa di antaranya, seperti karang dan krinoid (lili laut) masih hidup di bumi hingga saat ini, akan tetapi banyak pula seperti amonit (hewan bercangkang spiral) sudah mati. Ketika semua anggota satu jenis makhluk hidup sudah mati, mereka dikatakan punah (Colvin, 2004:4).

Moluska (filum moluska, dari bahasa Latin: molluscus yang berarti lunak) merupakan hewan triploblastik selomata yang bertubuh lunak. Kedalamnya termasuk semua hewan lunak dengan maupun tanpa cangkang, seperti berbagai jenis siput, kiton, kerang-kerangan, serta cumi-cumi dan kerabatnya. (Mulyo,2009:76). Sisa moluska bisa didapatkan dalam bentuk cangkang, karena bahan cangkang yang mengandung kapur tidak mudah terurai (dekomposisi) dalam tanah pada situs arkeologi dalam bentuk utuh, pecahan, sebagai artefak ataupun non artefak. Selain itu fosil moluska sangat penting untuk mengetahui lingkungan purba, menentukan umur batuan, perubahan iklim, serta regresi laut. Langkah kerja dalam mengidentifikasi moluska yaitu: 1. Pengumpulan di situs penelitian. 2. Labeling. 3. Pembersihan. 4 pengerjaan cangkang moluska di laboratorium meliputi: a. Pemilihan antara utuh dan pecahan pemilahan antara bentuk pipih (bivalves/pelecypoda) dan berpilin (univalves/gastropoda). b. Penghitungan jumlah dan penimbangan berat setiap spit/lapisan dari masing-masing kotak penggalian dan pengidentifikasian (modul praktek mata kuliah sejarah Indonesia 1, 2015:25).

Dalam penelitian fosil prasejarah di desa Sako ini peneliti menemukan berbagai macam jenis fosil antara lain: Family: Tellinidae. Nama Latin: Tellinidae rostrate. 2. Family: Turridae. Nama Latin: Drillia suturalis. 3. Family: Olividae. Nama Latin: Oliva elegans. 4. Family: Acmaeidae. Nama Latin: Acmaeidae borneensis. 5. Family: Architec tonicidae. Nama Latin: Architec tonicidae perdix. 6. Genus: Fusinus. Nama Latin: Fusinus colus. 7. Family: Sili Quaridae. Nama Latin

Siliquaria ponderosa. 8. Family: Conidae. Nama Latin: Conidae generalis. 9. Family: Cardiidae. Nama Latin: Discors lyratum. 10. Class: Scaphopoda. Nama Latin: Dentalium elephantinum. 11. Family: Fasciolariidae. Nama Latin: Latirus polygonus. 12. Family: Cymatiidae. Nama Latin: Biplex perca. 13. Family: Tridacnidae. Nama Latin: Tridacna squamosal. 14. Family: Buccinidae. Nama Latin: Hindsia magnifica. 15. Family: Veneridae. Nama Latin: Paphia amabilis. 16. Family: Turbinidae. Nama Latin: Turbinidae petholatus. 17. Family: Struthiola riidae. Nama Latin: Struthiolaria papulosa-papulosa. 18. Family: Pleurotomariidae. 19. Super Family: Cypraeacea. Nama Latin: Cypraeidae onyx. 20. Super family: Ceritheria. Family: Turritellidae. 21. Sufer Family: Cerithiacea. Family: Turritellidae. Nama Latin: T. terebra. 22. Family: Fasciolariidae. Nama Latin: Latirus poligonus. 23. Karang. 24. Family: Veneridae. Nama Latin: Paphia amabilis. 25. Family: Mactridae. Nama Latin: Spisula elliptica. 26. Genus: Strombus. Nama Latin: Strombus latus. 27. Family: Mytilidae. Nama Latin: Perna viridis. 28. Family: Glossidae. Nama Latin: Cerestoderma edule. 29. Family: Arcidae. Nama Latin: Anadara maculosa. 30. Family: Limidae. Nama Latin: Aequipecten 
opercularis. 31. Karang. 32. Super Family: Volutacea. Family: Olividae. Nama Latin: Olividae reticulate. 33. Family: Tridacnidae. Nama Latin: Tridacna squamosal. 34. Family: Arcidae. Nama Latin: Pteria leventi. 35. Family: Pinnidae. Nama Latin: Pinna incurve (Oliver, 2004:300)

Berdasarkan uraian diatas, maka berbagai jenis sumber pembelajaran hendaknya dipandang sebagai satu kesatuan yang utuh dalam proses pembelajaran. Semua jenis sumber belajar yang belum sesuai, perlu dipertimbangkan demi tercapainya pembelajaran yang lebih baik. Dengan demikian diharapkan akan berdampak positif terhadap hasil pembelajaran.

Pemahaman guru sejarah SMA Negeri 1 Sirah Pulau Padang tentang fosil prasejarah moluska di desa Sako dapat dijadikan sebagai sumber pembelajaran sejarah. Dengan mempelajari tentang fosil prasejarah moluska dapat menambah pengetahuan siswa tentang sejarah daerah sebagai upaya menambahkan rasa kecintaan siswa terhadap sejarah lokal.

Ketika pembelajaran sejarah mengenai materi tentang fosil prasejarah moluska, setiap siswa disuruh menyebutkan jenis-jenis moluska. Dengan sendirinya siswa akan berusaha untuk mencari informasi tentang jenis-jenis moluska. Sehingga dapat menambah pengetahuan siswa tentang sejarah lokal.

Dari hasil wawancara peneliti dengan bapak Drs. Andi Askar guru sejarah di SMA Negeri 1 Sirah Pulau Padang dapat diketahui bahwa guru sejarah SMA Negeri 1 Sirah Pulau Padang sudah memahami tentang fosil prasejarah moluska di desa Sako, dan bisa menempatkan materi tentang fosil prasejarah moluska di desa Sako sebagai materi sumber pembelajaran sejarah dikelas $X$, serta dapat di kembangkan dalam proses pembelajaran sejarah.

Dalam mata pelajaran sejarah kelas X SMA Negeri 1 Sirah Pulau Padang bahwa fosil prasejarah moluska di desa Sako termasuk pada Standar Kompetensi (SK) dan Kompetensi Dasar (KD) sebagai berikut:

1. Nilai sejarah yang terdapat dalam fosil prasejarah moluska di desa Sako merupakan suatu hasil dari proses alam dimana terjadinya secara alami terbentuk akibat dari proses alam yang terkubur selama jutaan tahun yang kemudian membentuk fosil. Pembahasan ini dapat dimasukkan dalam SK: 2. Menganalisis peradaban Indonesia dan dunia dan KD: 2.1 Menganalisis kehidupan awal masyarakat Indonesia.

2. Alasan fosil prasejarah moluska di desa Sako dimasukkan ke dalam SK: 2. Menganalisis peradaban Indonesia dan dunia dan KD: 2.1 Menganalisis kehidupan awal masyarakat Indonesia, adalah fosil prasejarah moluska di desa Sako merupakan jejak peradapan manusia purba yang berada di Indonesia, yang kemudian dianalisis untuk mengetahui jejak peradapan yang ada di desa Sako dan dapat di jadikan sebagai sumber pembelajaran sejarah untuk mengetahui jejak peradapan Indonesia.

Dari uraian diatas peneliti melakukan analisa kelebihan moluska sebagai sumber pembelajaran sejarah di SMA Negeri 1 Sirah Pulau Padang. Peluang bagi mahasiswa yaitu siswa dapat memperkenalkan fosil moluska yang ada di desa Sako sebagai benda cagar budaya, yang dapat di gali lebih dalam lagi dengan bekerja sama dengan pemerintah daerah atau pemerintah kabupaten sehingga peninggalan purba ini dapat di ketahui oleh orang banyak dan dapat dijadikan sebagai acuan untuk melakukan penelitian lanjutan serta dapat dijadikan sebagai sumber pembelajaran sejarah di SMA Negeri 1 
Sirah Pulau Padang. Kelemahan masyarakat setempat dalam memahami tentang fosil moluska sehingga masyarakat kurang tertarik terhadap fosil moluska ini, maka dari itu diperlukan peranan mahasiswa untuk memperkenalkan kepada masyarakat, sehingga ketika mendapatkan temuan terbaru dapat di laporkan. Ancaman yang akan dihadapi dalam menghadapi persaingan dunia kerja mahasiswa harus lebih pintar dalam memanfaatkan dan menguasai tentang fosil moluska yang ada di Sako sehingga dapat dijadikan sebagai salah satu kemampuan yang belum dimiliki oleh orang lain dalam hal memahami fosil moluska.

Fosil moluska yang ada di desa Sako harus terus dipelajari secara mendalam sehingga mahasiswa dapat mengembangkan penelitiannya secara lebih lanjut dan dapat menjadikan salah satu keunggulan yang dimiliki oleh mahasiswa.

\section{SIMPULAN}

Berdasarkan hasil penelitian dan pembahasan yang sesuai dengan tujuan penelitian dapat disimpulkan sebagai berikut:

1. Dari hasil olah data lapangan menunjukkan bahwa jumlah jenis moluska yang berhasil diidentifikasi di laboratorium pendidikan sejarah sebanyak 34 jenis moluska laut.

2. Diperkirakan moluska yang ditemukan dahulunya hidup di laut dangkal di pesisir pantai.

3. Temuan data lapangan menunjukkan ribuan tahun yang lalu kota Palembang dan sekitarnya dahulunya merupakan bagian dari garis pantai purba.

4. Data temuan lapangan menunjukkan bahwa data moluska desa Sako dapat dimasukkan dalam SK: 2. Menganalisis peradaban Indonesia dan dunia dan KD: 2.1 Menganalisis kehidupan awal masyarakat Indonesia.

\section{DAFTAR PUSTAKA}

Arikunto, Suharsimi. 2013. Prosedur Penelitian Suatu Pendekatan Praktek. Jakarta: Rineka Cipta.

Colvin, Leslie., Speare, Emma. 2004. The Usborne Living Word Encyclopedia Tumbuhan, Hewan, dan Alam. Jakarta:PT Gading Inti Prima.

Idris, Muhamad, dkk. 2015. Modul Praktek Mata Kuliah Sejarah Indonesia 1. Palembang: Universitas PGRI Palembang.

Kanang, Suadi. 2010. Sejarah Desa dan Masa Pemerintahan Desa Sako Jilid 1. Banyuasin: Kepala Desa Sako.

Mulyo, Agung. 2009. Pengantar IImu Kebumian Pengetahuan Geologi Untuk Pemula. Bandung: Pustaka Setia.

Oliver. 2004. Philip's. Guide to Seashells of The World. London: A CIP Catalogue Record for this book is available from the British Library.

Pranoto, Suharto W. 2006. Teori dan Metodologi Sejarah. Yogyakarta: Ombak.

Sugiyono. 2009. Metode Penelitian Kuantitatif Kualitatif dan $R \& D$. Bandung: Alfabeta.

Sutopo. 2006. Metodologi Penelitian Kualitatif, Dasar Teori dan Terapannya Dalam Penelitian. Surakarta: Universitas Sebelas Maret. Usman, Husaini., Akbar Setiady. 2014. Metodologi Penelitian Sosial. Jakarta: Bumi Aksara. 